\title{
Freshwater Snail Diversity in Mae Lao Agricultural Basin (Chiang Rai, Thailand) with a Focus on Larval Trematode Infections
}

\author{
Kittichai Chantima*, Krittawit Suk-ueng, Mintra Kampan \\ Energy and Environment Program, Faculty of Science and Technology, Chiang Rai Rajabhat University, Chiang Rai 57100, Thailand
}

\begin{abstract}
The aim of this study was to conduct a freshwater snail survey in Mae Lao agricultural basin to assess the diversity with a focus on habitat types and their larval trematode infections. Snails were collected and examined in 14 sites of Mae Lao agricultural basin from August 2016 to October 2017. A total of 1,688 snail individuals were collected and classified into 7 families, 8 genera, and 12 species. Snail diversity and habitat types were higher in rice paddies than irrigation canals and streams. The most abundant species was Bithynia siamensis siamensis, representing $54.6 \%$ of the sample. Three species of snails act as first intermediate host were found with cercarial infections. They were Filopaludina sumatrensis polygramma, B. s. siamensis, and Melanoides tuberculata. The cercariae were categorized into 7 types; echinostome, monostome, gymnocephalous, virgulate, parapleurolophocercous, pleurolophocercous and megalurous cercariae. Parapleurolophocercous cercariae constituted the most common type of cercariae recovered, contributing $41.2 \%$ of all infections in snails. Echinostome metacercariae infections were found in 6 snail species with $7.6 \%$ prevalence. In addition, the metacercaria of avian trematode, Thapariella sp. were found in Filopaludina spp. snails and $B$. funiculata with a prevalence of $0.5 \%$. This is the first report for Thapariella metacercariae in the snail host, $B$. funiculata, and also confirmed that viviparid and bithyniid snails act as the second intermediate hosts of this trematode. This work will provide new information on the distribution and intermediate host of trematode in this area.
\end{abstract}

Key words: Freshwater snail, trematode, cercaria, metacercaria, Mae Lao agricultural basin

\section{INTRODUCTION}

Freshwater snails act as first and second intermediate hosts of several trematodes that cause diseases in humans and animals such as echinostomiasis [1] and various food-borne trematodes $[2,3]$. The trematodes are of great medical and veterinary importance. They have a direct and indirect complicated life cycle involving vertebrate definitive host and snail intermediate host [4]. Several snail species may also serve as intermediate hosts of nematodes [5]. In Thailand, many species of freshwater snails were reported to be infected by larval trematodes, occasionally by nematodes [5-8]. The trematode infected with high prevalence in the North and Northeast of Thailand [9-11]. However, only a few studies have been concerned

\footnotetext{
- Received 23 April 2018, revised 6 June 2018, accepted 14 June 2018.

*Corresponding author (kittichai.cha@crru.ac.th)

(C) 2018, Korean Society for Parasitology and Tropical Medicine

This is an Open Access article distributed under the terms of the Creative Commons

Attribution Non-Commercial License (http://creativecommons.org/licenses/by-nc/4.0) which permits unrestricted non-commercial use, distribution, and reproduction in any

medium, provided the original work is properly cited.
}

with the larval trematode infectious potential in northern Thailand, particularly, Chiang Rai province. Thus, a study of larval trematode infection in freshwater snails in Chiang Rai province was carried out.

Mae Lao agricultural basin, located in the Mae Lao sub-river basin of Kok River basin in Mae Lao district, Chiang Rai province, Northern Thailand [12]. This forms the Mae Lao agricultural area where Mae Lao River is the main stream of the subbasin. It is the catchment area of many small rivers supplying the water that supports the livelihood of the people in the Mae Lao district. Mae Lao sub-river basin covers an area of 40,957.92 ha of Mae Lao district and has agricultural area of $16,496.8$ ha $[13,14]$. Land use of Mae Lao district comprises mainly rice production, vegetables and fruit trees-perennial crops. Some grows other crops such as maize and bean in the hilly area. About $20 \%$ of the total agricultural area is utilized for field crops [15]. Environmental changes following agricultural activities and irrigation development are likely to modify the pattern of distribution of snails and trematodes. Therefore, larval trematodes shed by snails could be used to assess envi- 
ronmental impact [16]. Documentation of the larval trematode fauna is also providing a more realistic understanding of the ecological settings in which snail borne diseases occur [17]. However, relatively few studies have dealt with the total snail and trematode fauna in this area.

Therefore, the present study attempted to determine whether freshwater snail diversity and prevalence of larval trematode infected snails in relation to habitat types. The purpose of the present note is to larval trematode infection in different snail species, and to provide baseline data for more comprehensive studies on the diversity of snail and parasite fauna which has not been thoroughly investigated so far in Mae Lao agricultural basin.

\section{MATERIALS AND METHODS}

\section{Study area}

The study was conducted from August 2016 to October 2017 in Mae Lao agricultural basin, which is located in the Mae Lao sub-river basin of Kok River basin in Mae Lao district, Chiang Rai province, Northern Thailand. Sampling sites were selected in consideration of the potential freshwater snail habitats and site accessibility in this agricultural area (Fig. 1). The geographical positions of sampling sites and habitat types were recorded and given in Table 1.

\section{Sampling and identification of freshwater snails}

The freshwater snails were sampled by using the counts per unit of time sampling method [18]. The sampling was conducted by the same 2 researchers at all sites for 30 min per site using a hand-picking and/or scooping method. Alive freshwater snails were brought to the laboratory, where they were identified to species according to taxonomic keys $[19,20]$. They were later examined for trematode infections.

\section{Examination for larval trematode infections}

Larval trematode infections were investigated by using shedding and crushing methods. The specimens were placed individually in $10 \mathrm{ml}$ bottles filled to half their capacity with dechlorinated tap water and checked for the shedding of cercariae by exposing them to artificial light for about $3 \mathrm{hr}$. Emerged cercariae were examined under the microscope and observed for their swimming behavior. Freshwater snails were screened, individually, for a period of $24 \mathrm{hr}$. The cercariae were studied vitally stained with $0.5 \%$ neutral red and mounted on slides and stained with hematoxylin or aceto-carmine. Details and morphologically cercariae types were identified based on gross characteristics according to Schell [21], Yamaguti [22] and Ito [23]. Sporocysts, rediae and metacercaria were examined under a dissecting microscope. Metacercariae were identified and counted by species of snails and the intensity determined.

\section{Data analysis}

The following indices were used to compare diversity and abundance of snails among habitats (rice paddy, irrigation canal and stream). First, diversity index is defined by the Shannon's diversity index [24-26]. A higher value indicated a large number of species with similar abundances, whereas a lower value indicated low diversity that was dominated by one or a few species [26]. Second, species evenness, this expressed as

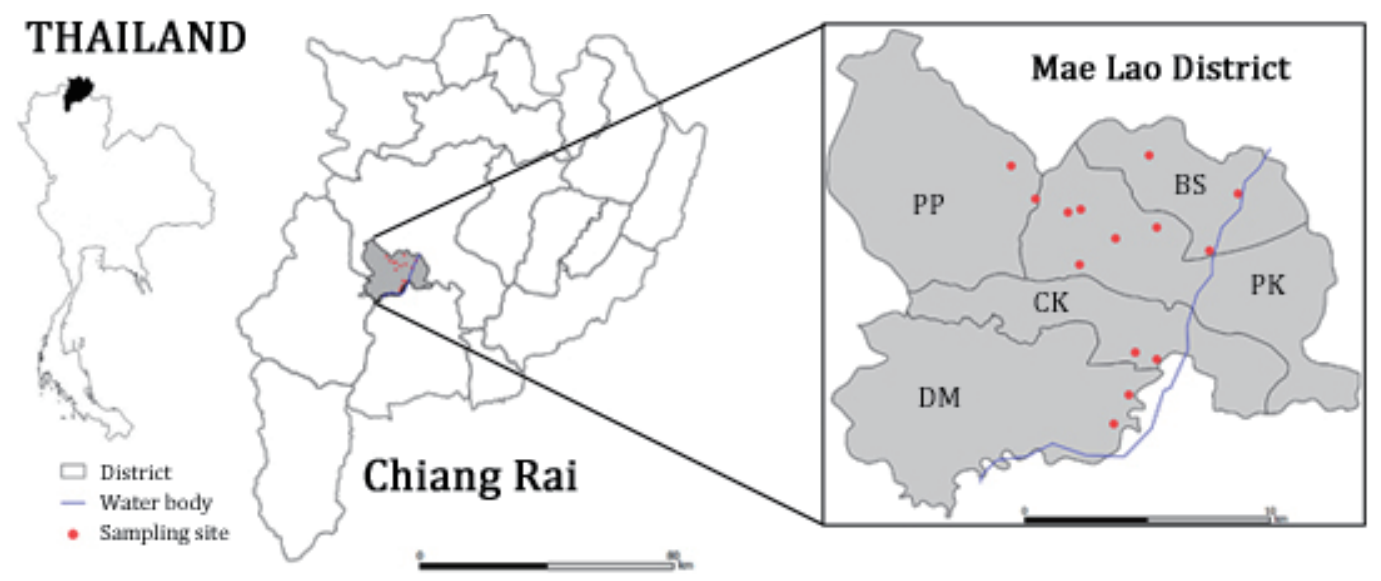

Fig. 1. Map showing location of the study area and sampling sites [69-70]: BS, Bou Sali Sub-district; CK, Chom Mok Keaw Sub-district; DM, Dong Mada Sub-district; PK, Pa Ko Dam Sub-district; PP, Pong Phrae Sub-district. 
Table 1. Site visited during field-work and total number of snails collected

\begin{tabular}{|c|c|c|c|}
\hline Sampling site & Coordinates (UTM) & Habitat types & $\begin{array}{c}\text { No. of snails } \\
\text { examined }\end{array}$ \\
\hline Ban Sri Wang Moon, Bou Sali Sub-district & 47Q 0579971,2190137 & Irrigation canal & 213 \\
\hline Ban Mae Tak, Bou Sali Sub-district & 47Q 0576564, 2191577 & Stream & 171 \\
\hline Ban Pa Ko Dam Mai, Pa Ko Dam Sub-district & 47Q 0578894, 2187948 & Rice paddy & 103 \\
\hline Ban Nong Bou, Pa Ko Dam Sub-district & $47 \mathrm{Q} 0576866,2188841$ & Rice paddy & 286 \\
\hline Ban San Ton Muang, Pa Ko Dam Sub-district & 47Q 0573961,2189497 & Irrigation canal & 108 \\
\hline Sub-district Administrative Organization bridge, Pa Ko Dam Sub-district & $47 Q 0573465,2189382$ & Stream & 54 \\
\hline Ban Mae Phong, Pa Ko Dam Sub-district & 47Q 0573923, 2187401 & Irrigation canal & 130 \\
\hline Ban San Nong Lom, Pa Ko Dam Sub-district & 47Q 0575290, 2188402 & Irrigation canal & 94 \\
\hline Ban San Pa Sak (1), Chom Mok Keaw Sub-district & 47Q 0576893, 2183806 & Irrigation canal & 81 \\
\hline Ban San Pa Sak (2), Chom Mok Keaw Sub-district & 47Q 0576074, 2184078 & Rice paddy & 123 \\
\hline Ban Rong Sala, Dong Mada Sub-district & $47 Q 0575837,2182466$ & Rice paddy & 112 \\
\hline Ban Pa Tung, Dong Mada Sub-district & $47 Q 0575252,2181352$ & Rice paddy & 93 \\
\hline Ban Mae Mon, Pong Phrae Sub-district & 47Q 0572223, 2189898 & Rice paddy & 20 \\
\hline Ban Pa Sang, Pong Phrae Sub-district & 47Q 0571279,2191158 & Stream & 100 \\
\hline
\end{tabular}

Pielou's evenness index [25,27]. This index expresses how evenly the individuals are distributed among the different species. Its values between 0 and 1 ; values closer to 0 represented uneven populations that were dominated by one species, while values closer to 1 represented even populations that were comprised of several species with similar abundances [28]. Snail counts and prevalence of infections based on simple descriptive statistics. Means are presented with their standard-errors.

\section{RESULTS}

\section{Diversity and distribution of snails}

We collected and examined a total of 1,688 individual freshwater snails of different species belonging to the families Viviparidae, Bithyniidae, Ampullariidae, Buccinidae, Thiaridar, Lymnaeidae and Corbiculidae. According to morphological evaluations, species of a total twelve snail species were identified (Fig. 2): Trochotaia trochoides, Filopaludina doliaris, F. martensi martensi, F. sumatrensis polygramma, Bithynia funiculata, $B$. siamensis goniomphalos, B. s. siamensis, Pomacea canaliculata, Clea helena, Melanoides tuberculata, Lymnaea auricularia, and Corbicula javanica. About half of all snails collected belonged to the Bithyniidae, with B. s. siamensis being the most common and abundant species, constituting $54.6 \%$ of the entire sample (Table 2). Bithyniid snails were particularly abundant in rice paddies and irrigation canals. B. siamensis goniomphalos were not recorded from irrigation canals and streams, while both $B$. funiculata and B. s. siamensis were found in all habitat types (i.e.

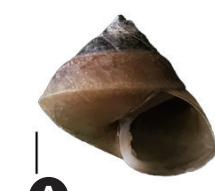

A

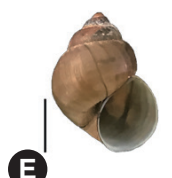

E

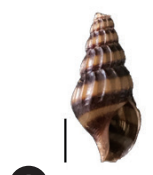

(1)

Fig. 2. Freshwater snails collected from Mae Lao agricultural basin: (A) Trochotaia trochoides; (B) Filopaludina doliaris; (C) F. martensi martensi; (D) F. sumatrensis polygramma; (E) Bithynia funiculata; (F) B. siamensis goniomphalos; $(\mathrm{G})$ B. s. siamensis; $(H)$ Pomacea canaliculata; (I) Clea helena; (J) Melanoides tuberculata; (K) Lymnaea auricularia; (L) Corbicula javanica. Scale bar $=0.5$ $\mathrm{cm}$.

rice paddy, irrigation canal, and stream). Thiarid snails, M. tuberculata were more commonly found in irrigation canals and streams than in paddy fields, while the greatest number of species was found in streams were T. trochoides, but this could be a result of the larger representation of this habitat. Diversity of snails was slightly higher in rice paddies (Shannon's diversity index $0.823 \pm 0.456, \mathrm{n}=6$ ) than in irrigation canals (Shannon's diversity index $0.747 \pm 0.516, \mathrm{n}=5$ ) and streams (Shannon's 
Table 2. Snail fauna and distribution in Mae Lao agricultural basin, and their diversity indices across 3 habitat types

\begin{tabular}{|c|c|c|c|c|c|c|c|c|c|c|c|c|}
\hline \multirow[b]{2}{*}{ Snail species } & \multicolumn{3}{|c|}{ Rice paddies $(n=6)$} & \multicolumn{3}{|c|}{ Irrigation canals $(n=5)$} & \multicolumn{3}{|c|}{ Streams $(n=3)$} & \multicolumn{3}{|c|}{ All habitats $(n=14)$} \\
\hline & $\begin{array}{l}\text { No. of } \\
\text { sites }\end{array}$ & $\begin{array}{l}\text { No. of } \\
\text { snails }\end{array}$ & $\%$ & $\begin{array}{l}\text { No. of } \\
\text { sites }\end{array}$ & $\begin{array}{l}\text { No. of } \\
\text { snails }\end{array}$ & $\%$ & $\begin{array}{l}\text { No. of } \\
\text { sites }\end{array}$ & $\begin{array}{l}\text { No. of } \\
\text { snails }\end{array}$ & $\%$ & $\begin{array}{l}\text { No. of } \\
\text { sites }\end{array}$ & $\begin{array}{l}\text { No. of } \\
\text { snails }\end{array}$ & $\%$ \\
\hline \multicolumn{13}{|l|}{ Viviparidae } \\
\hline Trochotaia trochoides & 0 & 0 & 0.0 & 0 & 0 & 0.0 & 1 & 89 & 27.4 & 1 & 89 & 5.3 \\
\hline Filopaludina doliaris & 2 & 8 & 1.1 & 0 & 0 & 0.0 & 0 & 0 & 0.0 & 2 & 8 & 0.5 \\
\hline Filopaludina martensi martensi & 6 & 34 & 4.6 & 3 & 26 & 4.2 & 1 & 10 & 3.1 & 9 & 70 & 4.1 \\
\hline Filopaludina sumatrensis polygramma & 5 & 59 & 8.0 & 3 & 62 & 9.9 & 1 & 5 & 1.5 & 9 & 126 & 7.5 \\
\hline \multicolumn{13}{|l|}{ Bithyniidae } \\
\hline Bithynia funiculata & 4 & 13 & 1.8 & 2 & 21 & 3.4 & 2 & 41 & 12.6 & 8 & 75 & 4.4 \\
\hline Bithynia siamensis goniomphalos & 2 & 3 & 0.4 & 0 & 0 & 0.0 & 0 & 0 & 0.0 & 2 & 3 & 0.2 \\
\hline Bithynia siamensis siamensis & 6 & 488 & 66.2 & 5 & 379 & 60.5 & 1 & 54 & 16.6 & 12 & 921 & 54.6 \\
\hline \multicolumn{13}{|l|}{ Ampullariidae } \\
\hline Pomacea canaliculata & 6 & 20 & 2.7 & 1 & 1 & 0.2 & 1 & 3 & 0.9 & 8 & 24 & 1.4 \\
\hline \multicolumn{13}{|l|}{ Buccinidae } \\
\hline Clea helena & 3 & 93 & 12.6 & 2 & 28 & 4.5 & 2 & 60 & 18.5 & 7 & 181 & 10.7 \\
\hline \multicolumn{13}{|l|}{ Thiaridae } \\
\hline Melanoides tuberculata & 1 & 17 & 2.3 & 1 & 100 & 15.9 & 1 & 63 & 19.4 & 3 & 180 & 10.7 \\
\hline \multicolumn{13}{|l|}{ Lymneidae } \\
\hline Lymnaea auricularia & 2 & 2 & 0.3 & 0 & 0 & 0.0 & 0 & 0 & 0.0 & 2 & 2 & 0.1 \\
\hline \multicolumn{13}{|l|}{ Corbiculidae } \\
\hline Corbicula javanica & 0 & 0 & 0.0 & 1 & 9 & 1.4 & 0 & 0 & 0.0 & 3 & 9 & 0.5 \\
\hline Shannon's diversity index & \multicolumn{3}{|c|}{$0.823 \pm 0.456$} & \multicolumn{3}{|c|}{$0.747 \pm 0.516$} & \multicolumn{3}{|c|}{$0.616 \pm 0.740$} & & & \\
\hline Pielou's evenness index & \multicolumn{3}{|c|}{$0.497 \pm 0.265$} & \multicolumn{3}{|c|}{$0.584 \pm 0.335$} & \multicolumn{3}{|c|}{$0.392 \pm 0.401$} & & & \\
\hline
\end{tabular}

diversity index $0.616 \pm 0.740, \mathrm{n}=3$ ). The evenness index was also higher in irrigation canals (Pielou's evenness index $0.584 \pm 0.335)$, whereas the rice paddies and streams were $0.497 \pm 0.265$ and $0.392 \pm 0.401$, respectively.

\section{Larval trematode infections Cercariae}

A total of 7 cercariae types were recorded (Fig. 3) and relative abundance of cercariae morphotypes and their infections in snails are summarised in Tables 3, 4. Cercariae were only identified to major type and more specific identification was not made, so these groups could well comprise of more species. M. tuberculata were found to be infected with 3 types of cercariae, including parapleurolophocercous, pleurolophocercous and megalurous cercariae. Whereas, 3 types of cercariae, monostome, gymnocephalus and virgulate cercariae were recorded in B. s. siamensis. Meanwhile F. s. polygramma served as hosts for echinostome cercariae. The most common type of cercariae recovered from the study area was parapleurolophocercous cercariae, which accounted for $41.2 \%$ of all infections in snails (Table 3). This was followed by virgulate cercariae (23.5\% of all infections) and megalurous cercaria (11.8\% of all infections). M. tuberculata was the host for pleurolophocer- cous cercariae in 2 habitats (irrigation canals and streams) with the prevalence of infection being highest in streams (Table 4).

\section{Metacercariae}

The investigation of trematode infection in total 1,688 freshwater snails from Mae Lao agricultural basin, there were 2 types metacercariae were observed in this study including Thapariella sp. and echinostome metacercariae. The overall infection rate and the number of metacercariae recovered from snail species are shown in Table 5. The most common metacercariae recovered from this study was echinostome, which accounted for $93.5 \%$ of all metacercariae recorded (Table 6). Total 129 of snails were infected with echinostome metacercariae. Throughout the course of our survey, a total of 1,401 echinostome metacercariae were recovered from 6 snail species, including F. doliaris, F. martensi martensi, F. sumatrensis polygramma, B. funiculata, B. s. siamensis, and $\mathrm{Cl}$. helena. The overall prevalence of infection was $7.6 \%(129 / 1,688)$. The infection rate varied from $0 \%$ to $47.1 \%$. Most metacercariae were recovered from viviparid and bithyniid snails. The intensity of infection ranged from 1.7 to 19.7 per snail infected, with a mean intensity of 11.4 per snail infected. 


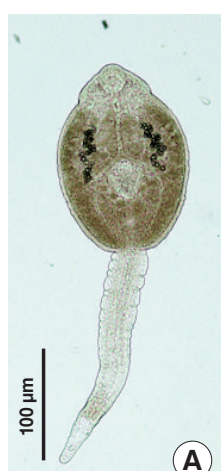

(A)
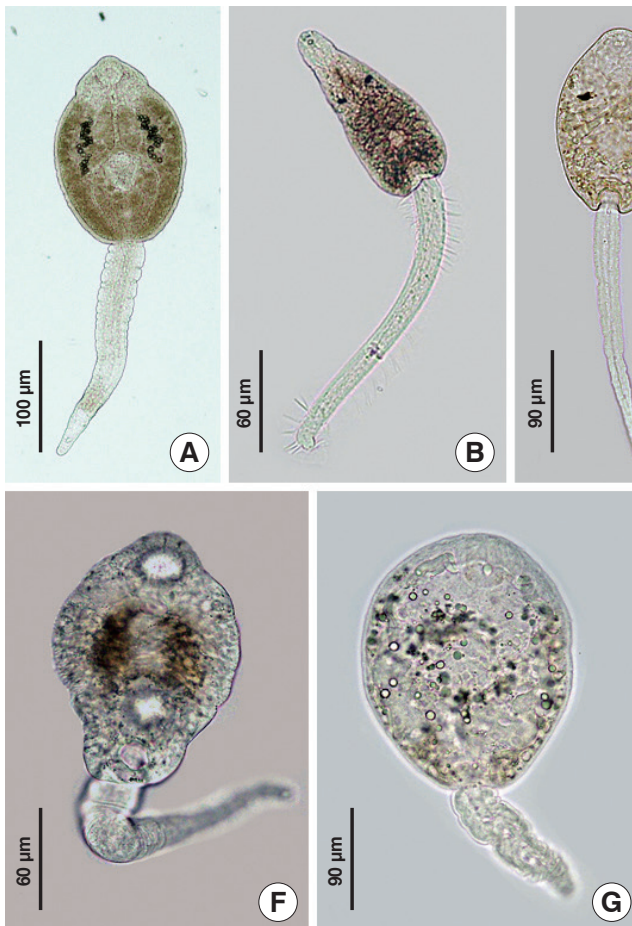
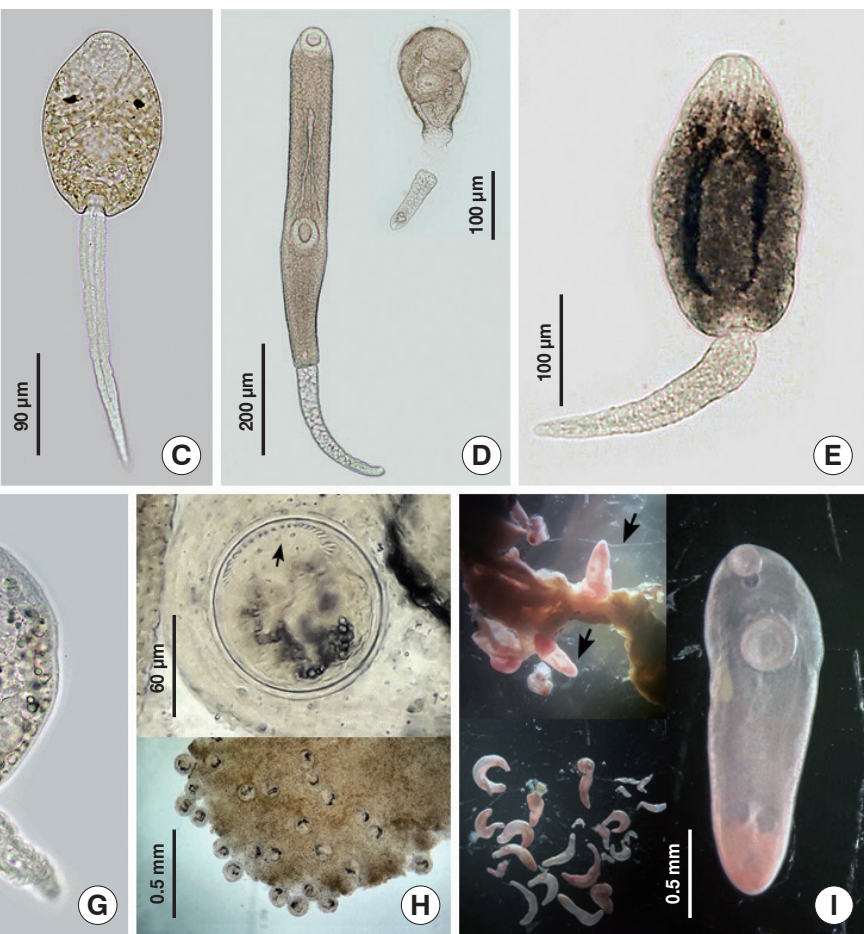

Fig. 3. Morphotypes of cercariae and metacercariae recorded from freshwater snail in Mae Lao agricultural basin. (A) Echinostome cercaria; (B) Parapleurolophocercous cercaria; (C) Pleurolophocercous cercaria; (D) Megalurous cercaria; (E) Monostome cercaria; (F) Gymnocephalus cercaria; (G) Virgulate cercaria; $(H)$ An isolated echinostome metacercaria showing head collar with collar spines (arrow); (I) An isolated metacercariae of Thapariella sp. The metacercariae were free, not encysted in the tissue of snail (arrows).

Table 3. Relative abundance (\% of all infection in snails) of cercariae morphotypes found in snails collected in Mae Lao agricultural basin

\begin{tabular}{lccccc}
\hline \multirow{2}{*}{ Morphotype of cercariae } & No. of infected snails & Relative abundance $(\%)$ & & No. of snail from \\
\cline { 4 - 6 } & & & Rice paddies $(n=6)$ & Irrigation canals $(n=5)$ & Streams $(n=3)$ \\
\hline Echinostome & 1 & 5.9 & 0 & 1 & 0 \\
Parapleurolophocercous & 7 & 51.2 & 0 & 0 & 1 \\
Pleurolophocercous & 1 & 11.8 & 0 & 0 & 1 \\
Megalurous & 2 & 5.9 & 0 & 1 & 0 \\
Monostome & 1 & 5.9 & 1 & 0 & 1 \\
Gymnocephalus & 1 & 23.5 & 1 & 1 & 0 \\
Virgulate & 4 & & & 0 \\
\hline
\end{tabular}

The Thapariella sp. were collected in $9(0.5 \%)$ out of 1,688 snails (4 species), i.e., F. doliaris, F. martensi martensi, F. sumatrensis polygramma, and B. funiculata, with their mean intensity of 7.2 per snails infected. The metacercariae of Thapariella sp. constituted about $6.5 \%$ of all metacercariae recorded (Table 6) and the infection status of Thapariella sp. by the snail species is revealed in Table 5. F. doliaris had the highest intensity (14 per snails infected) and the highest prevalence (25\%) of Thapariella sp. infection.

\section{DISCUSSION}

This study provides the first large scale analysis on freshwater snail diversity in Mae Lao agricultural basin. We detected a several species of freshwater snails along with their distribution in the different region sites. The present study has identified a total of 11 snail species and 1 species of clam in 14 selected sites, including rice paddies, irrigation canals and streams. Snail diversity is considerably higher in rice paddies than in irrigation canals and streams. B. s. siamensis is the most frequent snail species in the area, and this species are very 
Table 4. Number of snails examined for trematode infections and number of snails infected with cercariae among freshwater snails in Mae Lao agricultural basin

\begin{tabular}{|c|c|c|c|c|c|c|c|c|}
\hline \multirow[b]{2}{*}{ Snail taxon and cercariae type } & \multicolumn{2}{|c|}{ Rice paddies } & \multicolumn{2}{|c|}{ Irrigation canals } & \multicolumn{2}{|c|}{ Streams } & \multicolumn{2}{|c|}{ All habitats } \\
\hline & $\begin{array}{l}\text { No. of } \\
\text { snails }\end{array}$ & $\begin{array}{c}\text { Prevalence } \\
(\%)\end{array}$ & $\begin{array}{l}\text { No. of } \\
\text { snails }\end{array}$ & $\begin{array}{c}\text { Prevalence } \\
(\%)\end{array}$ & $\begin{array}{l}\text { No. of } \\
\text { snails }\end{array}$ & $\begin{array}{c}\text { Prevalence } \\
(\%)\end{array}$ & $\begin{array}{l}\text { No. of } \\
\text { snails }\end{array}$ & $\begin{array}{c}\text { Prevalence } \\
\text { (\%) }\end{array}$ \\
\hline Filopaludina sumatrensis polygramma & 59 & & 62 & & 5 & & 126 & \\
\hline Echinostome & 0 & 0.0 & 1 & 1.6 & 0 & 0.0 & 1 & 0.8 \\
\hline Bithynia siamensis siamensis & 488 & & 379 & & 54 & & 921 & \\
\hline Monostome & 0 & 0.0 & 1 & 0.3 & 0 & 0.0 & 1 & 0.1 \\
\hline Gymnocephalus & 3 & 0.6 & 1 & 0.3 & 0 & 0.0 & 4 & 0.4 \\
\hline Virgulate & 1 & 0.2 & 0 & 0.0 & 0 & 0.0 & 1 & 0.1 \\
\hline Melanoides tuberculata & 17 & & 100 & & 63 & & 180 & \\
\hline Parapleurolophocercous & 0 & 0.0 & 3 & 3.0 & 4 & 6.3 & 7 & 3.9 \\
\hline Pleurolophocercous & 0 & 0.0 & 0 & 0.0 & 1 & 1.6 & 1 & 0.6 \\
\hline Megalurous cercaria & 0 & 0.0 & 0 & 0.0 & 2 & 3.2 & 2 & 1.1 \\
\hline
\end{tabular}

Overall prevalence of infection (\%) is also given

Table 5. Prevalence and intensity of the metacercariae in freshwater snails in Mae Lao agricultural basin, Chiang Rai province, Thailand

\begin{tabular}{|c|c|c|c|c|c|}
\hline \multirow[b]{2}{*}{ Snail species } & \multirow{2}{*}{$\begin{array}{l}\text { No. of snail } \\
\text { examined }\end{array}$} & \multicolumn{2}{|c|}{ Echinostome } & \multicolumn{2}{|c|}{ Thapariella sp. } \\
\hline & & $\begin{array}{l}\text { No. of snail infected } \\
(\%)\end{array}$ & $\begin{array}{l}\text { No. of metacercaria } \\
\text { (intensity) }\end{array}$ & $\begin{array}{l}\text { No. of snail infected } \\
(\%)\end{array}$ & $\begin{array}{l}\text { No. of metacercaria } \\
\text { (intensity) }\end{array}$ \\
\hline Trochotaia trochoides & 89 & $0(0.0)$ & $0(0.0)$ & $0(0.0)$ & $0(0.0)$ \\
\hline Filopaludina doliaris & 8 & $3(37.5)$ & $59(19.7)$ & $2(25.0)$ & $28(14.0)$ \\
\hline Filopaludina martensi martensi & 70 & $33(47.1)$ & $634(19.2)$ & $3(4.3)$ & $6(2.0)$ \\
\hline Filopaludina sumatrensis polygramma & 126 & $48(38.1)$ & $584(12.2)$ & $3(2.4)$ & $30(10.0)$ \\
\hline Bithynia funiculata & 75 & $22(29.3)$ & $80(3.6)$ & $1(1.3)$ & $1(1.0)$ \\
\hline Bithynia siamensis goniomphalos & 3 & $0(0.0)$ & $0(0.0)$ & $0(0.0)$ & $0(0.0)$ \\
\hline Bithynia siamensis siamensis & 921 & $20(2.2)$ & $39(2.0)$ & $0(0.0)$ & $0(0.0)$ \\
\hline Pomacea canaliculata & 24 & $0(0.0)$ & $0(0.0)$ & $0(0.0)$ & $0(0.0)$ \\
\hline Clea helena & 181 & $3(1.7)$ & $5(1.7)$ & $0(0.0)$ & $0(0.0)$ \\
\hline Melanoides tuberculata & 180 & $0(0.0)$ & $0(0.0)$ & $0(0.0)$ & $0(0.0)$ \\
\hline Lymnaea auricularia & 2 & $0(0.0)$ & $0(0.0)$ & $0(0.0)$ & $0(0.0)$ \\
\hline Corbicula javanica & 9 & $0(0.0)$ & $0(0.0)$ & $0(0.0)$ & $0(0.0)$ \\
\hline Total & 1,688 & $129(7.6)$ & $1,401(10.9)$ & $9(0.5)$ & $65(7.2)$ \\
\hline
\end{tabular}

Table 6. Relative abundance (\% of all metacercariae recorded) of the metacercariae in freshwater snails from Mae Lao agricultural basin, Chiang Rai province, Thailand

\begin{tabular}{lccc}
\hline Metacercaria & No. recorded & Relative abundance (\%) & No. of sites where found \\
\hline Echinostome & 129 & 93.5 & 11 \\
Thapariella sp. & 9 & 6.5 & 6 \\
\hline
\end{tabular}

common in rice paddies and irrigation canals. On the other hand, the diversity of freshwater snail fauna of the Mae Lao agricultural basin seems to be considerably lower, according to the number of species as compare to other provinces of Thailand. Moreover, the golden apple snails, Pomacea canaliculata is not very abundant in this area which is in contrast to the findings by Chanyapeth and Achawakhom [29], that this snail is very abundant in rural areas of Thailand. This species is an alien species, it was imported from South America in 1988, and is now a serious agricultural pest causing significant damage to newly planted rice fields $[29,30]$. The present study showed that the freshwater snails were widely distributed throughout the Mae Lao agricultural basin though some of the snail species had a rather erratic pattern of distribution. Variability in snail diversity among sites was pronounced due to the specific agricultural at a given location. Obviously, rice 
paddies undergo the most pronounced seasonal changes due to paddy preparation, for rice transplanting and harvesting. In addition, the main factors affecting snail density would appear to be related to the agricultural practices including use of chemicals, some of which could have some molluscicidal activity [31].

Most freshwater snails can become intermediate hosts for trematode infections. Both gastropods and bivalves are utilized as the first and second intermediate hosts of trematodes [2,3]. This study revealed a high variety of freshwater snails in Mae Lao agricultural basin. Seven of the 12 snail species serve as the intermediates host of trematode and the results show that host snails and larval trematode infections were found in all 3 types of habitat surveyed. The 7 morphotypes of cercariae that are recorded from the present study showed similar trends in Chiang Mai province, North Thailand, where Chontananarth and Wongsawad [32] found 9 types of the trematode cercariae. Likewise, the infection rate varies in studies carried out in other province of Northern Thailand: 2 morphologically distinct types of larval trematodes infecting Melanoides sp. in Phrae province [33], 10 trematode species afflicting freshwater snails family Thiaridae in the Northern part of Thailand [34], Similarly, 4 morphologically distinguishable types of pleurophocercous cercariae were recorded in Chiang Mai province [35].

As shown by the results, the M. tuberculata were infected by parapleurolophocercous, pleurolophocercous and megalurous cercariae. Previously, parapleurolophocercous and pleurolophocercous cercaria have been recorded from snail species belonging to family Thiaridae, including M. tuberculata, Thiara scabra, Taribia granifera, and Sermyla riquetii [31,35-38]. The morphological characteristic of parapleurolophocercous and pleurolophocercous cercaria was discovered to reveal the cercarial stage of the intestinal tremaode in family Heterophyidae and Opisthorchiidae. The morphology of cercariae were similar to those described by previous reported $[35,37,38]$. This is in line with earlier findings $[39,40]$. In a previous study undertaken in Chiang Rai province, it was noted that most metacercariae infected in fishes belonged to the family Heterophyidae. This can be considered significant evidence to support the success of this study in the epidemiological situation of these trematodes in their intermediate hosts in this area. M. tuberculata were also infected by megarulous cercariae, which have been morphologically characterized as belonging to the genus Philophtalmus. Megalorouse cercariae lost their tails and encysted simultaneously on the surface of the bottom of the con- tainer (Fig. 3D). According to previous reports, the snail intermediate host of this cercaria was found in the same snail species $[41,42]$, while some were only found in other snail species belonging to the Family Semisulcospiridae, Semisulcospira libertine [43]. Regarding the snail hosts, B. s. siamensis were found to be infected with monostome, gymnocephalus and virgulate cercariae. Previous reports found the same type of cercariae in this snail from Chiang Mai province [32,44]. The cercariae fauna in our study area was quite diverse with 7 morphotypes, some of which might represent more trematode species and besides the fish-born zoonotic trematode types other species are potentially zoonotic, such as the echinostomes $[44,45]$. Echinostome cercariae were discovered in viviparid snail (F. $s$. polygramma), whereas several studies have reported identifying it in planorbid, lymnaeid and thiarid snails $[38,46,47]$, and they were reported to be present as the cercarial stage of the trematodes in family Echinostomatidae [48]. On the other hand, viviparid snails have been reported to play a role in second intermediate host of Echinostomatidae [44,45,48]. Echinostome cercaria developed in many important trematodes, particularly Echinostoma revolutum, E. malayanum, and Нүроdereaum conoideum [48]. Furthermore, E. revolutum is known to be the medically important zoonotic intestinal parasite in humans and also constitute public health problems especially in Southeast Asia and the Far East [49,50]. The remaining 9 species, i.e., T. trochoides, F. doliaris, F. m. martensi, B. funiculata, B. s. goniomphalos, P. canaliculata, Cl. helena, L. auricularia, and Co. javanica were found not to be infected with any cercariae in this study, however this is in contrast to other studies. For example, it was found that $L$. auricularia was the most important intermediate snail host for transmitting a wide variety of trematodes in Thailand [51,52]. Many records in Thailand pointed to Bithynia snails being the key link in the liver fluke, Opisthorchis viverrini. Today, 3 Bithynia taxa are recognized from the Mekong area as first intermediate hosts of O. viverrini: $B$. funiculata, B. s. goniomphalos, and B. s. siamensis [53]. Likewise, $\mathrm{Cl}$. helena were reported as the first and second intermediate hosts of intestinal trematode in Thailand, namely, Brevifurcate apharyngeate cercariae, Podocotyle (Podocotyle) lepomis, Brachylaima virginianum, and E. revolutum. Nevertheless, they are more rarely found to be infected parasitic trematodes than other snails $[44,54,55]$. Similarly, we did not find any cercariae shedding from freshwater calm, Co. javanica. Previously, bucephalid (Gasterostome) cercariae were found from clams of Thailand belonging to 2 species, Corbicula sp. and Limnoperna siamensis 
[56]. However, cercariae infection in the clams of Thailand have a few reported.

No cercariae infections were found in 9 snail species as above mention, but we found metacercariae in species of viviparid, bithyniid and buccinid snails. Throughout the course of our survey, echinostome metacercariae were recovered from 6 snail species, including F. doliaris, F. m. martensi, F. s. polygramma, B. funiculata, B. s. siamensis, and Cl. helena. Most echinostome metacercariae were recovered from viviparid snails. According to previous reports, also found echinostome metacercariae in these 3 snail families in Thailand $[6,19,44]$. In other areas of Southeast Asia viviparid species have been reported as second intermediate hosts for species of the Echinostomatidae $[45,57]$. Several species of freshwater snails have been reported to play as the first and second intermediate hosts of echinostomes in Thailand, namely, Bithynia spp., Cl. helena, Eyriesia eyriesi, Filopaludina spp., Gyraulus spp., Indoplanorbis spp., Lymnaea spp., Pila spp. and Viviparus spp. $[8,44,58]$. In this study, F. s. polygramma also play a dual role of the first and second intermediate hosts of echinostome. The mature echinostome cercariae may directly encyst as metacercariae within the same first intermediate host or leave the host, and penetrate and encyst in other snails of the same or different species [59].

Moreover, mixed infections with metacercariae of avian trematode, Thapareilla sp. were found in all viviparid snails and B. funiculata in this study. This trematode was first reported in viviparid snails in India [60], which probably occurs as an adult in the African openbill stork, Anastomus lamelligerus [61]. Rai and Pande [62] and Agrawal et al. [63] also reported on metacercaria of Thapariella found free and remarked that it is not encysted in snails Bellamya bengalaensis. On the other hand, Anucherngchai and Chontananarth [64] described adult stage of Thapariella sp. from snails, F. martensi and F. polygram$m a$ in Bangkok, Thailand. Whereas, the adult stage of Thapariella was recorded in esophagus of avian as previous reports $[61,65]$. Therefore, the morphological characteristics and biological features of this trematode should be redescribe in the future research. Recently, Thapareilla anastomusa also been reported in viviparid snails, F. doliaris and F. m. martensi from Phitsanulok province, Thailand [66]. With regard to B. funiculata, they appeared to be infected with Thapareilla sp., although they had never been considered to be of the intermediate host of this trematode previously $[16,60,62,66,67]$. Hence, detection of Thapareilla sp. in B. funiculata for the first time so far as the literature are concerned. Meanwhile, Thapareilla had never been reported in Chiang Rai province. This study represents the first report of Thapareilla in Chiang Rai province. However, there has been no report of Thapareilla infections in humans, but the viviparid and bithyniid snails carrying the infective stages of Thapareilla commonly consumed by birds, such as aquatic birds. Birds can become infected by eating these snails, may directly affected this trematode distribution in wild animals.

However, low numbers of infected snails with larval trematode were recorded in this study, and it has been reported that prevalence of larval trematode infections are dependent on snail numbers [68]. According to Chontananarth and Wongsawad [32], who suggested that the larva trematode infection in snails might be influenced by the anthropogenic factors and specific fauna in the observed regions, including microorganisms that could be the potential secondary or/and intermediate hosts of the larvae found in freshwater snails.

Conclusively, this study demonstrated that transmission of trematodes in this area. Seven morphotypes of cercariae and 2 metacercariae trematodes of medical and veterinary importance were found. In addition, this study reported new information on intermediate host of one species of avian trematode. This study gives valuable knowledge for research in biomedical and veterinary public health. It is also of great importance when considering the possibility of controlling snailborne trematode infections in this area. The further study should be intensive study the morphology and applying the molecular techniques for identifying larval trematodes.

\section{ACKNOWLEDGMENTS}

The authors gratefully acknowledge Chiang Rai Rajabhat University for financial support. Special thanks are given to the Energy and Environment Program, Faculty of Science and Technology, Chiang Rai Rajabhat University for providing facilities.

\section{CONFLICT OF INTEREST}

The authors declare that they have no conflicts of interests.

\section{REFERENCES}

1. Carney WP. Echinostomiasis--a snail-borne intestinal trematode zoonosis. Southeast Asian J Trop Med Public Health 1991; 22: 
206-211.

2. Chai JY, Darwin Murrell K, Lymbery AJ. Fish-borne parasitic zoonoses: status and issues. Int J Parasitol 2005; 35: 1233-1254.

3. Chai JY, Shin EH, Lee, SH, Rim HJ. Foodborne intestinal flukes in Southeast Asia. Korean J Parasitol 2009; 47 (suppl): 69-102.

4. Cheng TC. The Biology of Animal Parasitology. Philadelphia, USA. W.B. Saunders. 1964.

5. Tesana S, Srisawangwong T, Sithithaworn P, Laha T. Angiostrongylus cantonensis: experimental study on the susceptibility of apple snails, Pomacea canaliculata compared to Pila polita. Exp Parasitol 2008; 118: 531-535.

6. Burch JB, Lohachit C. Snail of medical importance in Thailand. Walkerana (Ann Arbor Mich) 1983; 1: 395-398.

7. Woodruff DS, Upatham ES. Snail transmitted diseases of medical and veterinary importance in Thailand and the Mekong valley. J Med Appl Malacol 1993; 4: 1-12.

8. Sri-Aroon P. Freshwater snails of medical importance in Thailand. Thailand: Mollusk Museum, Applied Malacology Center, Department of Social and Environmental Medicine, Mahidol University. 2011, pp 6-8.

9. Wongsawad C, Rojanapaibul A, Mhad-arehin N, Pachanawan A, Marayong T, Suwattanacoupt S, Rojtinnakorn J, Wongsawad P, Kumchoo K, Nichapu A. Metacercaria from freshwater fishes of Mae Sa stream, Chiang Mai, Thailand. Southeast Asian J Trop Med Public Health 2000; 31: 54-57.

10. Sithithaworn P, Haswell-Elkins M. Epidemiology of Opisthorchis viverrini. Acta Trop 2003; 88: 187-194.

11. Boonchot K, Wongsawad C. A Survey of helminthes in cyprinoid fish from the Mae Ngad Somboonchon reservoir, Chiang Mai province, Thailand. Southeast Asian J Trop Med Public Health 2005; 36: 103-107.

12. Mekong River Commission. The Mekong river commission basin development plan: Sub-area Report Chiang Rai Sub-area (SA 2T). Basin Development Plan Library. Bangkok, Thailand. 2005.

13. Janekarnkij P. Payment for ecosystem services (PES) as tool for Mae Lao watershed conservation. Department of Agricultural and Resource Economics, Faculty of Economics, Kasetsart University. Bangkok (Thailand). 2014. ARE Working Paper No. 2557/2.

14. Mae Lao District Agricultural Extension Office. Department of Agricultural Extension, Ministry of Agriculture and Cooperatives. Bangkok, Thailand. 2016.

15. Department of Water Resources. Ministry of Natural Resources and Environment. Bangkok, Thailand. 2006.

16. Lafferty KD. Environmental parasitology: what can parasites tell us about human impacts on the environment? Parasitol Today 1997; 13: 251-255.

17. Lockyer AE, Jones CS, Noble LR, Rollinson D. Trematodes and snails: an intimate association. Can J Zool 2004; 82: 251-269.

18. Olivier L, Schneiderman M. A method for estimating the density of aquatic snail populations. Exp Parasitol 1956; 5: 109-117.

19. Brandt RAM. The non-marine aquatic mollusca of Thailand. Archiv fur Molluskenkunde 1974; 105: 1-423.
20. Upatham ES, Sornmani S, Kitikoon V, Lohachit C, Burch JB. Identification key for fresh-and brackish-water snails of Thailand. Malacol Rev 1983; 16: 107-136.

21. Schell SC. Parasitology Laboratory Manual. Wiley. New York, USA. 1963.

22. Yamaguti S. A Synoptical Review of Life Histories of Digenetic Trematodes of Vertebrates. Tokyo, Japan. Keigaku Publishing Co. 1975, pp. 1-590.

23. Ito J. Studies on Cercariae in Japan. Shizuoka University. Shizuoka, Japan. 1980.

24. Washington HG. Diversity, biotic and similarity indices. Water Res 1984; 18: 653-694.

25. Clarke KR, Warwick RM. Change in marine communities: An approach to statistical analysis and interpretation. Plymouth, UK. PRIMER-E. 1994.

26. Hill D, Fasham M, Tucker G, Shewry M, Shaw P. Handbook of Biodiversity Methods: Survey, Evaluation and Monitoring. Cambridge, UK. Cambridge University Press. 2005.

27. Brewer R. The Science of Ecology. 2nd ed. New York, USA. Saunders College. 1994.

28. Hillebrand H. Dominance. In Jorgensen SE, Fath B eds, Encyclopedia of Ecology. Elsevier. Oxford, UK. 2008, pp 938-944.

29. Chanyapeth $\mathrm{CH}$, Achawakhom T. Golden apple snails. Bangkok: Proceedings of a seminar on the golden apple snail 1998; 3.13.15.

30. Greene SD. Extending integrated pest management to the golden apple snail: examining a community centre approach in northeast Thailand. Int J Pest Manag 2008; 54: 95-102.

31. Dung BT, Madsen H, The DT. Distribution of freshwater snails in family-based VAC ponds and associated water bodies with special reference to intermediate hosts of fish-borne zoonotic trematodes in Nam Dinh Province, Vietnam. Acta Trop 2010; 116: $15-23$.

32. Chontananarth T, Wongsawad C. Epidemiology of cercarial stage of trematodes in freshwater snails from Chiang Mai Province, Thailand. Asian Pacific J Trop Biomed 2013; 3: 237-43.

33. Mard-arhin N, Prawang T, Wongsawad C. Helminths of freshwater animals from five provinces in Northern Thailand. Southeast Asian J Trop Med Public Health 2001; 32 (suppl): 206-14.

34. Dechruksa W. Cercarial infections of freshwater snails family Thiaridae in the northen part of Thailand. [master's thesis]. [Nakornpathom]: Silpakorn University; 2006 (in Thai).

35. Chontananarth T, Wongsawad C. The pleurophocercous cercariae infection in snail Family Thiaridae Grey, 1847 Northern, Thailand. Asian Pac J Trop Dis 2017; 7: 205-210.

36. Dechruksa W, Krailas D, Ukong S, Inkapatanakul W, Koonchornboon T. Trematode infections of the freshwater snail family Thiaridae in the Khek River, Thailand. Southeast Asian J Trop Med Public Health 2007; 38: 1016-1028.

37. Krailas D, Namchote S, Rattanathai P. Human intestinal flukes Haplorchris taichui and Haplorchris pumilio in their intermediate hosts, freshwater snails of the families Thiaridae and Pachychilidae, in Southern Thailand. Zoosyst Evol 2011; 87: 349-360. 
38. Krailas D, Namchote S, Koonchornboon T, Dechruksa W, Boonmekam B. Trematodes obtained from the thiarid freshwater snail Melanoides tuberculata (Müller, 1774) as vector of human infections in Thailand. Zoosyst Evol 2014; 90: 57-86.

39. Nithikathkul C, Wongsawad C. The occurrence of heterophyid metacercariae in freshwater fish from reservoirs. Asian Biomed 2008; 2: 229-232.

40. Suntaravitun P, Dokmaikaw A. Prevalence of trematode metacercariae in cyprinoid fish from Rim Kok sub-district, Mueang Chiang Rai District, Chiang Rai Province. J Mahanakorn Vet Med 2014; 9: 113-120 (in Thai).

41. Daniela V, Elena VL. Larvas de digenea en Melanoides tuberculata (Gastropoda: Thiaridae) En Medellín, Colombia. Acta biol Colomb 2009; 14: 135-142.

42. Pinto HA, Melo AL. Melanoides tuberculata as intermediate host of Philophthalmus gralli in Brazil. Rev Inst Med Trop Sao Paulo 2010; 52: 323-327.

43. Urabe M. Cercariae of a species of Philophthalmus detected in a freshwater snail, Semisulcospira libertine, in Japan. Parasitol Int 2005; 54: 55-57.

44. Chantima K, Chai JY, Wongsawad C. Echinostoma revolutum: Freshwater snails as the second intermediate hosts in Chiang Mai, Thailand. Korean J Parasitol 2013; 51: 183-189.

45. Chai JY, Sohn WM, Na BK, Nguyen VD. Echinostoma revolutum: metacercariae in Filopaludina snails from Nam Dinh Province, Vietnam, and adults from experimental hamsters. Korean J Parasitol 2011; 49: 449-455.

46. Fernández MV, Hamann MI, Ostrowski-de Núñez M. Echinostome cercariae from Biomphalaria straminea (Mollusca: Planorbidae) in a ricefield from northeastern Argentina. Rev Mex Biodivers 2014; 85: 1024-1031.

47. Anucherngchai S, Tejangkura T, Chontananarth T. Epidemiological situation and molecular identification of cercarial stage in freshwater snails in Chao-Phraya Basin, Central Thailand. Asian Pac J Trop Biomed 2016; 6: 539-545.

48. Esteban JG, Muñoz-Antoli C. Echinostomes: systematics and life cycles. In Toledo RM, Fried B eds. The Biology of Echinostomes: From the Molecule to the Community. New York, USA. Springer. 2009, pp 1-34.

49. Haseeb MA, Eveland LK. Human echinostomiasis: mechanisms of pathogenesis and host resistance. In Fried B, Graczyk TK eds, Echinostomes as Models for Biological Research. Dordrecht, Netherlands. Springer. 2002, pp 83-98.

50. Chai JY. Echinostomes in humans. In Toledo RM, Fried B eds. The Biology of Echinostomes: From the Molecule to the Community. New York, USA. Springer. 2009, pp 147-183.

51. Charoenchai A, Tesana S, Pholpark M. Natural infection of trematodes in Lymnaea (Radix) auricularia rubiginosa in water reservoirs in Amphoe Muang, Khon Kaen Province. Southeast Asian J Trop Med Public Health 1997; 28: 209-212.

52. Chontananarth T, Tejangkura T, Wetchasart N, Chimburut C. Morphological characteristics and phylogenetic trends of trematode cercariae in freshwater snails from Nakhon Nayok Prov- ince, Thailand. Korean J Parasitol 2017; 55: 47-54.

53. Petney TN, Sithithaworn P, Andrews R, Kiatsopit N, Tesana S, Grundy-Warr C, Ziegler A. The ecology of the Bithynia first intermediate hosts of Opisthorchis viverrini. Parasitol Int 2012; 61: 3845.

54. Krailas D, Chotesaengsri S, Dechruksa W, Namchote S, Chuanprasit C, Veeravechsukij N, Boonmekam D, Koonchornboon T. Species diversity of aquatic mollusks and their cercarial infections; Khao Yai National Park, Thailand. J Trop Med Parasitol 2012; 35: 37-47.

55. Yutemsuk N, Krailas D, Anancharoenkit C, Phanpeng L, Dechruksa W. Trematode infections of freshwater snails genus Clea A. Adams, 1855 in the reservoir of lower northeast Thailand. JITMM Proceedings 2017; 6: 7-16.

56. Krailas D, Chotesaengsri S, Pattaradussadee N., Notesiri N, Dechruksa W. Bucephalid (Gasterostome) cercariae obtained from freshwater clams in Thailand. J Trop Med Parasitol 2008; 31: 7076.

57. Madsena H, Hung NM. An overview of freshwater snails in Asia with main focus on Vietnam. Acta Trop 2014; 140: 105-117.

58. Pariyanonda S, Tesna S. Edible mollusc, the intermediate host of helminths in Khon Kaen Province, Thailand. Srinagarind Med J 1990; 5: 159-172 (in Thai).

59. Rim HJ. Echinostomiasis. In Hillyer GV, Hopla CE eds. CRC Handbook Series in Zoonoses, Section C: Parasitic Zoonoses, Vol. III. Trematode Zoonoses. Boca Raton, USA. CRC Press. 1982, pp 53-69.

60. Srivastava NN. On the morphology and systematic position of a new avian trematode Thapariella anastomusan. g, n. sp., with a suggestion on the creation of a new family Thapariellidae. Indian J Helminthol 1953; 5: 101-108.

61. Prudhoe S. Trematoda. Trematoda. Exploration du Parc national de l'Upemba. Fasc, 48. 1957, pp 1-28.

62. Rai DN, Pande BP. On the metacercariae of Thapariella anastomusa Srivastava,1955. Indian J Helminthol 1967; 19: 64-69.

63. Agrawal N, Pandey KC, Kiran GB. Record of metacercaria of Thapareilla anastomusa Srivastava, 1958, from Bellamya bengalensis (L.). Indian J Helminthol 2002; 20: 35-38.

64. The Prevalence and Morphological Characteristic of Trematodes Infection in Freshwater Snails, Filopaludina in Khlong Toey market, Bangkok, Thailand. The 4th Academic Science and Technology Conference 2016. Bangkok, Thailand. 2016, pp $92-97$ (in Thai).

65. Agarwal SM. Further observations on Thapariella anstastomusa Srivastava, 1953 (Trematoda: Thapariellidae). Indian J Helminthol 1958; 10: 40-45.

66. Phalee W, Phalee A, Wongsawad C. New record of Thapariella anastomusa (Trematoda: Thapariellidae) metacercariae in Northern Thailand. Korean J Parasitol 2018; 56: 49-52.

67. Panday KC, Agrawal N. Metacercarial fauna of India. Kolkata, India. Rec Zool Surv India 2013; 349: 1-310.

68 . Ewers WH. The influence of the density of snails on the incidence of larval trematodes. Parasitol 1964; 54: 579-583. 
69. Geo-Informatics and Space Technology Development Agency (GISTDA). L05_GISTDA_Tambon_2012 [Data file]. Bangkok: Geo-Informatics and Space Technology Development Agency 2012.
70. QGIS Development Team. QGIS Geographic Information System. [Internet]; Available from: https://www.qgis.org/en/site/. 2017. 
